Lucian GEORGE

University of Oxford, England

\title{
Interpreting Alexander Chayanov's Peasant Utopia since 1991
}

\author{
Interpretacje chłopskiej utopii Aleksandra Czajanowa po 1991 r.
}

\section{- Abstract •}

Composed in 1919 as a rebuke to Bolshevik rule, Alexander Chayanov's utopian story about a future, peasant-dominated Russia has fascinated scholars from a wide variety of disciplines. This article provides a critical overview of the Russian- and English-language scholarship on Chayanov's peasant utopia that has emerged over the last three decades. The intellectual and ideological contexts in which the text has been situated are explored and compared. The article also discusses how the utopia has been understood in ideological and political terms, and how scholars have wrestled with ambiguities arising from its relativism, parodic qualities and potentially dystopian elements.

Keywords: Alexander Chayanov; literary utopia; utopianism; Russian Revolution; peasants; agrarianism; ideology; anti-communism; Narodniks (Populists); dystopia

\section{- Abstrakt •}

W 1919 r. rosyjski ekonomista Aleksander Czajanow napisał utopijną opowieść, przedstawiającą alternatywną wizję rosyjskiej przyszłości Rosję zarządzaną przez chłopów i wolną od bolszewizmu. Od kilku dziesięcioleci, szczególnie od upadku ZSRR, Czajanowska utopia regularnie przyciąga uwagę badaczy z różnych dziedzin. Niniejszy artykuł przedstawia krytyczną ocenę i syntezę rosyjsko- oraz angielskojęzycznej literatury przedmiotu powstałej po $1991 \mathrm{r}$. Szczególną uwagę poświęcono temu, jak badacze starali się usytuować utopię w odmiennych kontekstach myślowych oraz jak dopatrywali się rozmaitych, nieraz sprzecznych, ideologii i ustrojów politycznych w opowieści. Omawiane są także problemy interpretacyjne związane z niejasnościami, które wynikają zarówno z relatywistycznej postawy autora, jak i parodystycznych i dystopijnych motywów w jego opowieści.

Słowa kluczowe: Aleksander Czajanow; utopia literacka; utopizm; rewolucja październikowa; chłopi; agraryzm; ideologia; antykomunizm; narodnicy; dystopia 
Though stylistically clumsy and largely ignored at the time, The Journey of $M y$ Brother Alexei to the Land of Peasant Utopia ranks amongst the most beguiling texts to emerge from the utopian fervour of the Russian Revolution (Stites, 1989). Written in 1919 by the agrarian economist Alexander Chayanov and published in 1920, The Journey imagined an alternative future to that being championed by the Bolsheviks - a future founded on the triumph of the peasants and the peasant economy. Entirely set in the Russia of the future, Chayanov's story recounted the adventures of Alexei Kremnev, a fictional socialist dignitary living in the thoroughly Bolshevised Moscow of 1921 (as imagined in 1919). Though a veteran of the workers' movement, Kremnev could not help feeling a guilty alienation from the socialist utopia he had fought for - an ineffable disappointment with its newspeak and groupthink (Orwellian notions that Chayanov obviously lacked, but was still able to convey), its disregard for history and repression of both the individual and the family. After wistfully reflecting on the utopian thinkers of the past, but nevertheless denying the possibility of an alternative non-socialist future, Kremnev suddenly found himself "teleported" into the Moscow of 1984. Though seemingly triumphant in the early 1920s, the world socialist revolution had, in fact - as Kremnev now discovered - been quickly brought down by rekindled national rivalries. In the newly redivided world, Russia had jettisoned the (essentially Germanic) bureaucratic socialism imposed by the Bolsheviks and reverted, after a political struggle won by the peasants, to a path that harmonised with its overwhelmingly rural demographics. In this new, peasant-dominated Russia, family life with all its cosy pleasures had been fully restored; central government was minimal and society largely self-governed; cities were banned by law, with their services and industries dispersed throughout the provinces; a love of both high culture and peasant tradition permeated the everyday world, whilst creativity was encouraged at every step; and a modernised, yet labour-intensive, agriculture, organised around small family farms and vertically integrated through cooperative enterprises, lay at the core of economic and spiritual life. Decentralised, peasant-dominated and mostly free of state coercion, the Russia of 1984 was antithetical to the war communism that reigned in 1919. Mistaken for an American visitor, Kremnev was taken on a tour of this alternative utopia in the company of one of its chief ideologues, Alexei Minin. Though increasingly enamoured of the utopia's norms (and women), Kremnev grew uneasy as the more elitist side of utopian governance was revealed to him. After a tense debate with Minin about the utopia's system of rule, Kremnev finally fell prey to suspicions of espionage, resulting in his incarceration.

Alexander Chayanov (1888-1937), the author of The Journey, was an intellectual with a polymathic range of interests and talents - many of them reflected in the 
utopia. An aficionado of history and art and an activist in the cooperative movement, Chayanov is best-known for his academic work on (and defence of) the peasant economy, much of it produced in the 1920s amidst heated debates between Marxists and supposed "neo-Narodniks" - a label that encompassed Chayanov. Most famously, Chayanov elaborated a microeconomic theory of the labour-based peasant household. Building on the work of his fellow agronomists in the so-called Organisation and Production School (henceforth OPS), Chayanov posited that the peasant farm, owing to its unity with the household and its basis in unpaid family labour, ran on principles that were substantively different from those governing capitalist firms. In his view, not only did the specificity of the peasant economy disqualify the use of the standard categories of neoclassical economics to make sense of it, but it also gave peasant farming a competitive edge and shielded peasants from processes of class differentiation (Thorner, 1986; Kerblay, 1986).

With its abundance of art, cooperatives, historical fetishism and of course peasant farming, Chayanov's utopia was a deeply personal vision, incorporating many of its author's passions and building on the normative implications of his academic views. Even so, Chayanov chose to publish his utopia under a pseudonym. Though he had briefly served as an assistant minister in the Provisional Government, Chayanov refused to go into exile or to join the Whites after the Bolshevik coup, instead opting to serve the Soviet government throughout the 1920s as an expert in agricultural affairs. By publishing his utopian polemic with Bolshevism pseudonymously, Chayanov hoped to avoid attracting political heat ${ }^{1}$. Whilst he managed to avoid persecution during the years of war communism and the NEP, in the long run such precautions failed to protect Chayanov. In 1930 - in the midst of the collectivisation campaign and increasingly vehement attacks on the "neo-Narodniks" - Chayanov was arrested and accused of involvement in a counter-revolutionary peasant party. Despite the lack of evidence for these charges, the OGPU interrogator would still "[find] everything he needed" in The Journey's vision of peasant rule (Bourgholtzer, 1999, p. 36). With Chayanov's purging - culminating in his execution in 1937 - Chayanov's writings too would disappear from public view.

Rediscovered in the West in the 1960s right as Third World revolutions and decolonisation were invigorating interest in peasants, Chayanov's translated writings would reverberate throughout the social sciences and provide a major impetus for the emergent discipline of "peasant studies" (Bernstein \& Byres, 2001; Mendras,

1 Rather surprisingly, The Journey would be published by a state agency, albeit at the price of a devastating Marxist foreword in which its contradictions were deconstructed and its reactionism exposed. 
2002, pp. 161-163). Indeed, it was in one of the early issues of the Journal of Peasant Studies, the main Anglophone venue for the discussion (and criticism) of Chayanov, that The Journey was first made available in English. In the USSR, meanwhile, the memory and study of Chayanov's work would remain suppressed until his rehabilitation in 1987. Since then, however, interest in Chayanov and his utopia has flourished amongst Soviet/Russian scholars, with new studies on The Journey appearing every decade.

As an economic/political disquisition disguised as a story - a hybrid of academic and fiction genres - The Journey has invited attention from a much greater variety of disciplines than any of Chayanov's other writings. Further contributing to this interdisciplinary appeal are the utopia's many puzzles - some of them directly connected to its mixing of genres. Understanding The Journey is significantly complicated by its endless parodying of the utopian genre and the intertwinement of utopian and dystopian features in the peasant utopia's construction. Equally beguiling is the fusion of modern and archaic, democratic and elitist elements - a hybridity which belies Chayanov's clear-cut characterisation of his future Russia as a specifically "peasant utopia". By invoking values and adopting methods associated with a variety of political traditions, The Journey also defies easy ideological categorisation; indeed, scholars have - with varying reflexivity, but rarely any acknowledgement of mutual incompatibility - characterised the text (or aspects of it) as both socialist (Raskov, 2014) and anti-socialist (Brass, 1996), "conservative-traditionalist"2 (Nikulin, 2017, p. 18) and modernist (Bruisch, 2018, p. 146), pluralistic (Nikulin, 2018) and totalitarian (Pavlova, 2005, pp. 334-344).

As this last point suggests, for all its interdisciplinary appeal Chayanov's text has failed to generate much in the way of academic debate. Rather, scholars from different disciplines have largely ignored one another's work on The Journey. As a result, multiple, sometimes overlapping, but also frequently divergent interpretations have been produced in relative autonomy. To compensate for this lack of dialogue, the present review article will provide an integrated and critical overview of the last thirty years of Russian- and English-language scholarship on The Journey. Besides summarising the most distinctive interpretations, the article considers how different contextualisations have brought into relief different dimensions of the text; identifies aspects of the utopia that have generated most interest and disagreement; and, finally, evaluates the merit of different interpretations, whilst also pointing out areas that have been overlooked or misunderstood. The article is divided into three sections, each with its own guiding question. These are as follows: (i) What politi-

\footnotetext{
2 All quotations from this and other Russian texts are my own translations.
} 
cal and intellectual contexts have scholars used to situate Chayanov's utopia and how have these framing choices shaped interpretations of the text?; (ii) How has the utopia been classified in ideological and political terms (e.g., liberal utopia, totalitarian society, etc.) and what are the strengths and weaknesses of different classifications?; (iii) How have the text's content and literary form informed interpretations of Chayanov's authorial intentions? In particular, how should the presence of potentially negative elements in Chayanov's imagined Russia be reconciled with its presentation as a utopia?

\section{Contexts}

Penned in the midst of the Russian Civil War and structured as a rebuke to Bolshevik policies and ambitions, Chayanov's utopia has first and foremost been considered as a response to the Russian Revolution. Whilst this proximate genealogy is obvious to all, scholars have also sought to embed the text in a variety of larger contexts, differing in spatial and temporal scale as well as their degree of historical specificity. In part, as will be shown, this contextual variety grows out of disagreements regarding the nature of The Journey's ideological character and of its relationship to the Revolution. More often, however, this contextual diversity has resulted from a diversity of research questions and, as such, has not led to incompatible framings. As will also be shown, a considerable virtue of this variety of contexts is that in each instance The Journey has been related to a different constellation of texts, bringing different dimensions of the utopia to light.

The broadest contextualisation - both spatial and temporal - to which Chayanov's utopia has been subject can be found in the work of the Marxist scholar Tom Brass, formerly a leading voice in British peasant studies. In the 1990s, Brass moved beyond his regional specialisations in India and Peru to pursue a crusade against the postmodernist and populist tendencies emerging throughout the academic Left. To Brass' chagrin, these tendencies had replaced traditional Marxist concepts in peasant studies (e.g., class, revolution) with populist categories (e.g., everyday resistance, moral economy, new social movements) whose implications Brass (1991) rejected as fundamentally conservative. It was in the context of his wider Marxist counter-offensive that Brass turned his attention to Chayanov's utopia. In a 1996 article Brass grouped Chayanov's text alongside the American novel Caesar's Column (1890) and the English novel and later American film Lost Horizon (1933/1937), arguing that all three exemplified a recurrent populist tendency - manifest in the 1890s, the 1930 s, but also the 1990 s - towards the construction of agrarian utopias - a uto- 
pianism that was deep down animated by the fear not so much of capitalism (notwithstanding anti-capitalist themes) as of socialism. The agrarian utopia - despite its façade of communitarian solidarity and seemingly anti-big business, justiceoriented ethos that might have rendered it seductive to the postmodern Left - was really the product of a reactionary impulse: an anti-modern (and hence quixotic) desire to turn back the clock in order to escape the possible dystopia of socialism, whilst still allowing some form of capitalism to survive in its imagined arcadia. To be fully understood, Chayanov's text had to be treated as a specific instantiation of a global populist reaction to the crisis of capitalism and associated threat of socialism - a reaction that would periodically re-erupt in different countries throughout the late $19^{\text {th }}$ and $20^{\text {th }}$ centuries. In Brass' article (1996), therefore, the specific historical and literary context in which Chayanov's utopia was produced would be relegated to the background and the utopia's typological features as a mere example of a much larger populist anti-socialism brought to the fore.

Unfortunately, the image of Chayanov's text emerging from Brass' primarily typological analysis was significantly impoverished. Trawling The Journey for the conservative and anti-socialist features associated with his "ideal type" of agrarian populist utopianism (e.g., subordination of man to nature, an anti-historical suspension of time, anti-industrialism), Brass was certainly able to identify some correspondences - of varying persuasiveness - between Chayanov's utopia and this ideal type. All the same, by shoehorning Chayanov into his largely supra-historical model, Brass stripped The Journey of nuance, ambiguity and historical context, flattening and distorting the text in the process. By way of example, Brass insinuated that Chayanov's laissez-faire vision of the utopian state and anti-bureaucratic critique of the socialist economy betrayed his affinity with the political Right (1996, p. 169) - as if Left forms of anti-bureaucratism and anti-statism had not been influential in early $20^{\text {th }}$-century Russia. Further, Brass interpreted the utopian de-urbanisation programme, presented in Chayanov's text as a response to "the danger to a democratic regime from huge conglomerations of urban population" (Kremnev, 1976, p. 79), as a clear-cut expression of specifically anti-proletarian fears (Brass, 1996, p. 170). He also reduced the moral of The Journey to an unequivocal vindication of its utopian vision ("Alexei Kremnev repents and rejects his socialism in favour of populism") - an oddly one-sided reading given that Kremnev ended his stay in the peasant utopia in prison (1996, p. 158).

Whilst none of the subsequent scholarship on The Journey has engaged with Brass' interpretation, his narrow insistence on the anti-modernist dimensions of Chayanovan agrarianism has received some pushback. In her work on agricultural experts, German historian Katja Bruisch has contested the relevance of a back- 
ward-looking agrarian myth, underpinned by nationalist or conservative impulses, to the motivations of the expert circles to which Chayanov belonged. Instead, Bruisch argued for a more nuanced understanding of agrarianism as "a 'pragmatic ideology', oscillating between two poles: an idealisation of rural life in the spirit of conservatism [...] on the one hand, and, on the other, the idea of an agrarian modernity" in which peasant farming was modernised rather than abolished (2012, pp. 145-147).

Where Brass framed The Journey as a particular instantiation of an almost atemporal anti-socialism, other scholars have preferred to treat it less as a reaction against the Revolution and more as a product of the emotional and ideological energies that the Revolution unleashed. This framing has, in turn, led scholars to consider The Journey in the context of other utopian texts emerging in the Revolution's aftermath and not just - as was the case for Brass - those which supposedly espoused the same political values. In some cases, this has meant comparing The Journey to utopian texts which - though ideologically different - shared its thematic interests (Clark, 1985). In others, however, The Journey has been compared with texts that shared little with it other than their utopianism. An example of the latter type can be found in an article by sociologist Aleksandr Nikulin, which set out to compare Chayanov's "liberal-conservative" utopia - also characterised as the "pink' progressive utopia of a moderate agrarian-socialist" committed to the ideals of the February Revolution - with Andrei Platonov's 1928 novel Chevengur, an "anarchocommunist" attempt to develop "the most radical ideals" of the October Revolution (2018, pp. 262, 286). Whilst both texts were infused with the "democratic romanticism of the Revolution", Nikulin sought to show how their "understandings of democracy and romanticism" differed and how each exemplified different utopian "types" (conceived in a similarly supra-historical fashion to Brass' "ideal type" of agrarian populism): the elitist utopianism of the "utopian chancellor", the stateaffiliated intellectual à la Sir Thomas More (or indeed à la Chayanov), on the one hand; the demotic utopianism of the "utopian vagabond", the wandering poet, on the other (2018, pp. 257-259).

The differences between Chayanov's and Platonov's utopian visions emerge clearly from Nikulin's comparison. Much less clear are the benefits one can derive from viewing them together given the absence of substantive similarities, shared intellectual roots or mutual influences between the two. In this respect, the equally comparative contextualisation pursued in an earlier article by literary and cultural historian Katerina Clark would prove much more productive. Instead of pairing Chayanov's utopia with an unrelated "opposite", Clark treated Chayanov as part of "duel" between urbanist and anti-urbanist literary utopias in post-1917 Rus- 
sia, all of which - their ideological diversity notwithstanding - shared Chayanov's concern with the countryside's fate after the Revolution. By considering Chayanov in this context, Clark was able to identify points not just of divergence, but also convergence, between Chayanov and alternative urbanist/anti-urbanist strands of thought. The picture of Chayanov's utopia that Clark offered was, indeed, that of a hybrid intermediary between the outright anti-modernism of the "muzhik socialist" tradition represented by Nikolai Klyuev and the unapologetic urbanist triumphalism of the Bolsheviks (1985, p. 181).

An equally productive but broader contextual framing was that adopted by the literary scholar O.A. Pavlova, whose extensive analysis of Chayanov's literary output was situated in a much longer monograph on literary utopianism during the socalled Silver Age in Russian culture (1900s-1920s). This contextualisation enabled Pavlova to connect many of The Journey's apparent idiosyncrasies to the cultural and literary tendencies of the Russian Silver Age. Thus, Pavlova traced how many of the values with which Chayanov sought to infuse his utopia stemmed simultaneously from Chayanov's own intellectual-professional career and the cultural context in which this career was formed. For instance, the penetration of artistic rhetoric into the peasant utopia's economic and political spheres ${ }^{3}$ reflected not just the polymathic range of Chayanov's own activities or his belief in the unity of science and art, but also the broader "mythologemes" of the "Russian Renaissance" (as the Silver Age is alternately referred to) (Pavlova, 2005, pp. 246-248). Similarly, the aestheticization of everyday life and universal penchant for historical role-play ${ }^{4}$ on display in the peasant utopia spoke not just to Chayanov's own antiquarian and artistic interests 5 , but also the more general "Decadentist" sensibility of Russian culture in this period (Pavlova, 2005, pp. 253, 258-259).

Having discussed some of the main contextual framings (i.e., $20^{\text {th }}$-century antisocialism; revolutionary utopianism; Silver Age culture) used to illuminate Chay-

${ }^{3}$ In his discussions with Kremnev, Alexei Minin defended peasant labour as a form of artistic creation ("Every workman is a creator, each manifestation of his individuality represents the art of work"), just as he cast the political creators of the utopia as "artists" engaged in a Promethean task (Kremnev, 1976, pp. 88, 101).

${ }^{4}$ Even a cursory reading of The Journey will reveal the omnipresence, indeed the primacy, of art and history in its inhabitants' lifeworld: casual conversations revolved around art; adolescents competed by producing still lifes that aimed to be "more Dutch"; old buildings and ruins were lovingly preserved, whilst traditional games (e.g., knuckle-bones) and costumes were revived, etc. (Kremnev, 1976, pp. 77, 81, 84 and passim).

5 Like his socialist alter ego Alexei Kremnev, the real Chayanov was a prolific collector of icons, books and engravings, as well as a lover of Muscovite history and antiquities; during the Revolution he lobbied for the protection of Russia’s cultural heritage (Pavlova, 2005, pp. 248-249). 
anov's utopia, it is worth considering one contextualisation which remains underrepresented in the literature on The Journey. This is the broader complex of agrarian/ peasantist movements and thinkers which existed in Europe, especially its more easterly regions, in the early-to-mid- $20^{\text {th }}$ century. As Brass argued, Chayanov's utopia shared much with this broader ideological tendency. Nevertheless, given that Brass related Chayanov's text to a (somewhat uncharitable) "ideal type" of agrarian populism rather than any of its concrete historical manifestations, the relationship between Chayanov and "really existing" agrarian movements remained unexplored in his article. The likelihood of such a relationship was alluded to by historian Il'ia Gerasimov (1997, pp. 148-150) when he pointed out the similarity between many of the policies adopted by Chayanov's utopia, on the one hand, and Alexander Stamboliyski's contemporary peasantist government in Bulgaria, on the other. Following the Bolshevik victory in the Civil War, Prague, the seat of the International Agrarian Bureau (an International of the main peasant parties of East-Central Europe), became an important node in Russian émigré agrarianism ${ }^{6}$, further increasing the likelihood of transnational ideological transfer between Russian and other agrarianisms. Even if the intellectual and personal ties between Chayanov's ideas and the agrarianism of foreign groups were not (yet) direct in 1919-1920, considering Chayanov's utopia in this broader context would remain useful - both to the ideological mapping of agrarianism within Europe and Russia (where OPS-style agrarianism remains under-researched relative to its more radical Narodnik cousin), and to see how far Chayanov's utopia conformed to the ways other European agrarianisms envisioned the future?

\section{Classifications}

Whilst the correspondence between Chayanov's utopia and agrarian ideology is striking, this has not stopped scholars from attributing The Journey to a variety of (partially conflicting) political traditions. Besides reflecting the relative obscurity of Russian agrarianism, such classificatory chaos owes much to the overlap between agrarianism and other political traditions - especially in the Russian con-

${ }^{6}$ By way of example, it was in Prague that the former Social Revolutionary Sergei Maslov set up the Labouring Peasant Party in 1921 and that Pitirim Sorokin published his Ideologiia agrarizma [The Ideology of Agrarianism] in 1924.

7 For more on the how the morphological variations of specific ideologies can be mapped, see Freeden (1996). For more on Russian agrarianism as a tradition apart from the Narodniks, see Bruisch (2012). 
text, where OPS-style agrarianism lacked the major organisational vehicle needed to give its ideology sharper (and less porous) contours. Conflicting classifications, however, also stem from the particular qualities of Chayanov's political outlook, namely his open-mindedness and eclecticism (Shanin, 1986, p. 16). Though it might seem contradictory to classify Chayanov's utopia as simultaneously socialist and anti-socialist, etc., different scholars' contrasting emphases often reflect a genuine diversity of ideological echoes within the text. This section will consider these different echoes and the arguments that have been (or could be) made for assigning the text to one tradition or another. It will also discuss the difficulty of defining the peasant utopia's political system and how some scholars' attempts at doing so might have fallen short.

\section{2.i. Ideologies}

Socialist elements. Though undoubtedly critical of the October Revolution, sceptical of the Left's most audacious ambitions to remake society and post-socialist in its own self-understanding ${ }^{8}$, Chayanov's utopia could still be seen as converging with the socialist tradition in certain regards. As will be shown, whether or not it is assigned to the socialist tradition largely depends on which aspects of it are considered.

Whilst private peasant farms formed the bedrock of Chayanov's utopian economy - in contravention of most socialists' preference for some form of collectivisation - utopian agriculture would nevertheless be partially socialised thanks to an extensive system of cooperatives charged with coordinating those branches of agricultural production where economies of scale could be found. Cooperatives were allowed, indeed encouraged, to monopolise specific markets through the discriminatory taxation of capitalist enterprises (Kremnev, 1976, pp. 90-91). It was precisely the privileged status granted to cooperativism combined with the circumscription of capitalism's role in the utopian economy that led economist Danila Raskov to characterise it as an exercise in "peasant socialism" (2014, paragraph 13).

8 To signal the peasant utopia's break with socialism, Minin referred to socialism in historical terms ("in the socialist period of history") and, somewhat ironically, subjected socialist ideology to the kind of materialist critique that the Left usually considers as its own prerogative: "Socialism was conceived as the antithesis of capitalism; born in the dungeons of the German capitalist factories, nurtured in the minds of an urban proletariat haunted by forced labour [...] it could conceive of an ideal system only as the negation of the system it knew" (Kremnev, 1976, p. 89). 
Militating against Raskov's conclusion is the fact that in the early $20^{\text {th }}$ century cooperativism was promoted by a variety of political movements, precluding any automatic equation of cooperativism with socialism. Indeed, the stated goal which cooperativisation was supposed to serve in The Journey was not socialism, but that of "establish[ing] a twentieth-century nation on the basis of the peasant farm and the peasant way of life" (Kremnev, 1976, p. 88). Besides not fashioning itself in openly socialist terms, Chayanov's cooperativised peasant economy was - as Raskov himself argued - deliberately constructed such as to avoid some of the problems Chayanov perceived in socialist economics, particularly its socially alienating tendency towards state monopolies and counter-productive reliance on coercion?.

Nevertheless, it could be argued that The Journey presented less an external critique of and corrective to socialism than an internal one. The rhetoric with which Minin legitimised the utopian economy betrayed clear engagement with socialist thought. Cooperativisation was, for instance, presented as a form of collectivisation - albeit one juxtaposed to "state collectivism" (Kremnev, 1976, p. 90) - and the promotion of peasant labour as a superior solution to the degrading separation of "labour" from "creative management" (Kremnev, 1976, p. 90) - that is, to something resembling the problem of alienation as defined by the early Karl Marx ${ }^{10}$. Connectedly, Minin's reference to "the variety" of peasant life (Kremnev, 1976, p. 88) as one of its distinguishing virtues was a possible echo of Marx's famous remark, in The German Ideology, about the overcoming under communism of the division of labour which prevented the same person from hunting in the morning and criticising after dinner ${ }^{11}$. More research into Chayanov's pre-1917 and post1917 thought is needed to assess whether these socialist echoes constituted integral elements of his thinking, a discursive effect of the post-1917 dialogue between agrarians like Chayanov and their socialist interlocutors/adversaries or, finally, an attempt to legitimise non-socialist ideas through invocation of a newly authoritative socialist discourse (Gal, 2019).

9 Problems like these were sidestepped in the utopia by accommodating (limited) market competition, allowing social self-management and preserving family households in which labour incentives did not have to be generated through coercive mechanisms (Kremnev, 1976, pp. 89-90; Raskov, 2014, paragraphs 30-31).

${ }^{10}$ In Chayanov's utopia, however, this "alienation" (a word that is never used in the text) is addressed primarily as a problem of the socialist, rather than capitalist, economy.

11 To my knowledge, the "variety" of peasant life was not an important theme in agrarian populist discourse elsewhere in Eastern Europe, increasing the likelihood that Chayanov's reference to it was an implicit allusion to Marx. 
Narodnik (Populist) elements. The fact that accusations of "neo-Populism" were a staple of Communist attacks on the OPS in the 1920s has lent enduring interest to the question of whether Chayanov's work should be included in the Narodnik tradition (Coleman \& Taitslin, 2008, pp. 91-92). Scholars who have recently argued in favour of such an inclusion, partly on the basis of The Journey, include Australian researchers William Coleman and Anna Taitslin, as well as the previously mentioned O.A. Pavlova. The principal arguments in favour of this view are obvious enough: in considering peasant agriculture a pre-/non-capitalist mode of production, advocating a peasant-led - rather than industrial - path of non- $/$ post-capitalist development for Russia and opposing the state-led centralisation of the economy, Chayanov and his utopia mirrored some of the Narodniks' most central beliefs (Coleman \& Taitslin, 2008, pp. 92-93). In other regards, however, Chayanov's thought deviated from traditional Narodnik articles of faith - most notably because Chayanov, in line with most of the OPS, had no interest in the peasant commune and showed more concern with improving and cooperativising agricultural production than in land reform or socialisation ${ }^{12}$. Whilst acknowledging this, Coleman and Taitslin (2008, p. 93) nevertheless argue that Chayanov's deviation was fully in line with the positions of moderate Narodniks organised around the Labouring Popular-Socialist Party (est. 1906). Meanwhile, as Pavlova pointed out (2005, p. 330), the list of convergences between Chayanov's utopia and the Narodnik tradition could be extended to include their shared faith in scientific/technical progress, cultural orientation towards the West and (seemingly) atheistic worldview.

An obvious problem for the Narodnik reading is that The Journey offers no explicit recognition of any such ideological paternity. In his utopia, just as in his broader career, Chayanov showed little appetite for party politics ${ }^{13}$. Indeed, the peasant takeover of Russia in The Journey was spearheaded by "purely class-based peasant associations" rather than political groupings; if anything, political groupings - in the form of Socialist Revolutionary (i.e., Neo-Narodnik) parties - would

12 Even though in 1917 Chayanov had reviewed land reform proposals as part of his work for the League of Agrarian Reform (Coleman \& Taitslin, 2008, pp. 94-95), the fact that no mention of land reform was made in The Journey could testify to Chayanov's limited interest in this question. Il'ia Gerasimov (1997, p. 144) even suggests that the small size of farm plots in the peasant utopia constituted a challenge to the old Narodnik belief positing that land hunger was the biggest obstacle to rural progress.

13 A preference for cooperative/agronomic over party-political activism was a general characteristic of the OPS and partially explains why Katja Bruisch (2012) opted to treat its agrarianism as separate from the Narodnik tradition. 
act as an obstacle to the peasants' march to power (Kremnev, 1976, p. 87). Given Chayanov's unwillingness to recognise the text's possible Narodnik genealogy, it seems arbitrary to consider features like the utopia's faith in science or its apparent atheism - attitudes over which the Narodniks were far from possessing an ideological monopoly - as specifically Narodnik traces.

Ultimately, however, the most persuasive argument against a strongly Narodnik reading of Chayanov's work comes from rural sociologist Teodor Shanin. Given the porous boundaries between the Marxist and Narodnik traditions and Chayanov's openness to a variety of influences, attempts to tether Chayanov's thought to a single ideology typically conceal more than they explain (Shanin, 1986, p. 18). Whilst there were certainly considerable overlaps between Narodnik ideology and Chayanov's utopia - far more so than for the other ideologies considered in this section reducing the latter to an expression of the former would simply be to overplay the contribution made by Narodnik ideology in shaping Chayanov's views ${ }^{14}$.

Liberal elements. At the beginning of The Journey Kremnev scoffingly dismissed liberalism as an alternative to socialism on account of its inability to "creat[e] ideologies [and] Utopias" (Kremnev, 1976, p. 74) ${ }^{15}$. No other reference to liberalism was made in Chayanov's text. Nevertheless, Aleksandr Nikulin (2018, p. 275) has argued for the centrality of liberal themes to The Journey. Key to this argument is the great importance attached by utopian society to pluralism - the belief, in Minin's words, "that life is worthwhile when it permits the full realisation of all the possibilities, all the new departures, contained in it" (Kremnev, 1976, p. 89). Whilst the utopia's leaders were hardly free of normative preferences, an ethos of pluralistic relativism would ensure their agrarianism adopted a "magnanimous" attitude towards its opponents: "the state and the market, industry and the town, capitalism and socialism all [had] the right to exist in the land of peasant utopia", even if in a subordinate position (Nikulin, 2017, p. 28). In addition, a distaste for state coercion and preference for social self-management would lead the utopia's architects to embrace a form of non-governmental, social governance closely resembling the (predominantly liberal) ideal of civil society (Nikulin, 2017, p. 17).

${ }^{14}$ Indeed, Shanin posits that "one should best take as true Chayanov's own explanation of his views as rooted in study of Russian agriculture of which he had so superb a knowledge” (1986, p. 18).

15 This dismissal has itself been subject to contradictory interpretations. Where Gerasimov (1997, p. 140) assumed that Kremnev's view of liberalism stood in for Chayanov's, economic historians William Coleman and Anna Taitslin (2008, p. 97) arrived at the opposite conclusion: by dismissing liberals' inability to create utopias Kremnev was in a sense throwing down the gauntlet to liberalism, whilst Chayanov was taking it up on liberalism's behalf. 
Whilst there is little to criticise in the substance of Nikulin's claims about the utopia's socio-political order, it is less obvious whether it could plausibly be described as liberal. The peasant utopia may have been emphatically pluralistic and free from state coercion, but it showed no interest in celebrating such classic liberal ideals as equality before the law, individual rights, consent of the governed or indeed freedom itself. On the contrary, some of these values would be subject to significant and unabashed violations, e.g., through the state's active disregard for fair economic competition between private and cooperative enterprises and its willingness to employ manipulative techniques of governance (discussed below) ${ }^{16}$. In view of these seeming inconsistencies, more research would be needed to explain Chayanov's selective interest in some liberal values and indifference to others.

Conservative elements. Amongst the most frequently observed tensions in Chayanov's utopia is the pairing of utopian audacity with frequently conservative ends (Coleman \& Taitslin, 2008, p. 97; Gerasimov, 1997, p. 154; Clark, 1985, p. 180). On the one hand, Chayanov's text oozed a "high modernist" confidence in the rationalistic reengineering of society and nature ${ }^{17}$. In the new Russia, landscapes were radically redrawn by fiat (the abolition of cities, "rectangles of common forest [emphasis mine]", etc.); human talents were optimally exploited; the weather was controlled; elites were self-proclaimedly Promethean; and the sophisticated technologies needed to keep a non-industrial, rural society connected could be effortlessly wished into being (Kremnev, 1976, pp. 82, 100, 101; Gerasimov, 1997, p. 144). At the same time, the social order that these engineering efforts were meant to serve was often a conservative one. Full of reverence for the past, utopian elites consciously deferred to the forces of (human) nature and history, and the limits they set on utopian ambition. Bolshevik - and to some degree Petrine (Clark, 1985, p. 180) revolutionism was shown to fail in no small part because it had underestimated such limits. The Communists' internationalism, for instance, had collapsed because "no socialist dogma could expunge the ideas of military revenge from the German soul"; their abolition of the family had foundered, for "the family is the family, and ever shall be"; and their efforts at nationalising agriculture had been defeated by the sheer size of the hostile Russian peasantry (Kremnev, 1976, pp. 86, 83). By contrast, the peasant utopia would be stabilised by its determination to go with the grain of history and nature, accepting "the law of diminishing returns"

${ }^{16}$ For a similar contestation of the liberal reading, see Coleman and Taitslin (2008, p. 98).

17 Not coincidentally, both Kremnev and Minin were engineers by profession. For more on the concept of "high modernism", see Scott (1998). 
in agriculture (with its negative implications for mechanisation) and basing itself not on "new principles [but] the old, centuries-old, principles on which from time immemorial the peasant economy had been based" (Kremnev, 1976, pp. 84, 88).

What, then, was the relationship between this conservatism and the utopia's more modernist aspects? At one level, the relationship appeared to be complementary: it was the valorisation of natural laws and historical legacies (conservatism) that motivated transformative measures (modernism) designed to safeguard and enhance these conservative values ${ }^{18}$. And yet many of the resultant transformations were so far-reaching as to deny a conservative reading some of its credibility: was peasant life really being "conserved" when utopian leaders flooded it with high culture and urban infrastructure? What is more, the values that Chayanov's utopians most wanted to conserve were hardly in line with the traditional priorities of Russian conservatism (Robinson, 2019): rather, this was a conservatism that had little time for Orthodoxy, empire and status hierarchy and an active preference for (some kind of) democracy over other systems of social organisation. Given the utopians' penchant for the Old Masters of the West, even their cultural neo-Slavophilism proved rather eclectic. In short, like all other ideological epithets, so the "conservative" label can only very partially capture the ideological physiognomy of Chayanov's utopia.

\section{2.ii. Utopian Governance}

Besides struggling to determine which ideological features best define The Journey, scholars have also disagreed on the proper description of its political order. On the one hand, the limited role assigned to the utopian state and its tolerance for extensive social self-organisation have inclined scholars to see the utopia in laissez-faire terms: be it, in Nikulin's more charitable version (2017, p. 17), by assimilating it to the idea of civil society or, in Brass' less charitable reading (1996, p. 169), by using the utopia's anti-statism as proof of its anti-proletarian class character. On the other hand, scholars' attention has also been drawn to the more manipulative, obtrusive and elitist facets of utopian governance. The practices of civic and elite formation put in place by the utopia - obligatory journeying for the young, artificial

18 As Minin put it, "our only aim was to assert these great ancient principles, to enhance their cultural value, to transform them spiritually and to endow their embodiment with a social and technical organisation which would enable them not only to display that peculiarly passive resilience which has characterised them for ages, but also to have active strength, elasticity and, if you like, striking power" (Kremnev, 1976, p. 88). 
legislative threats to peasant interests designed purely "to arouse peasant social consciousness" and mass surveillance with a view to the identification and cultivation of talents (Kremnev, 1976, pp. 99-101) - have even led to comparisons with totalitarian systems of rule (Gerasimov, 1997, p. 153; Coleman \& Taitslin, 2008, p. 98; Pavlova, 2005, pp. 334-344). The totalitarian analogy would receive its fullest development in Pavlova's work, where the manipulation of popular consciousness by utopian elites was described as a dystopian "desacralisation of [man's] inner world", a portent of practices later employed in Nazi Germany (2005, p. 336). In Pavlova's view, this totalitarian governance extended even to the creation of a supposed "neoreligion" based on the veneration of the arts and the sciences (2005, pp. 338-343).

What such totalitarian interpretations typically overlook is the stated rationale behind some of the utopian regime's more morally dubious practices. Far from striving to mobilise the utopian public around a new ideological orthodoxy, Chayanov's utopian elites aspired only to create a functional, self-sustaining public sphere. Aware of the difficulties in fostering civic and cultural life in the countryside, but determined to minimise the state's coercive presence, utopian elites were forced to resort to a partially invisible, indeed manipulative, form of social engineering in order to arrive at their goal (Kremnev, 1976, pp. 99-101). This goal, however, was much more about spiritual activisation than political indoctrination, thought stimulation rather than thought control. By mistaking one for the other, the totalitarian reading at best eliminates a deliberate ambiguity in Chayanov's utopia or, at worst, distorts its intended meaning ${ }^{19}$.

Related to the question of the utopia's political order is that of its ruling class and class character. Though the Russia of 1984 was declared a "peasant utopia", the primacy of its peasantry can easily be questioned. Notably, Kremnev's guides the utopia's architects - were all drawn from artistic-intellectual echelons, whilst the peasants' role was limited to that of a colourful (and largely passive) backdrop (Nikulin, 2018, pp. 264-265). Their peasantness, moreover, appeared to have been sanitised and civilised in line with elite preferences ${ }^{20}$. Indeed, according to French

19 For an egregious example of such distortion, we might consider Pavlova's treatment of the passage where Minin explained how the peasant regime had had to find new ways to stimulate art in the absence of wealthy patrons and a leisure class in the democratised world (Kremnev, 1976, p. 97). For Pavlova, this discussion betrayed a desire to manipulate art, by replacing its autonomous production - never mind if this autonomy had relied on vast social inequality - with "the replication of loyal content and fossilized art forms" (Pavlova, 2005, p. 343).

${ }^{20}$ By way of example, the new peasant settlements with their "fine avenues" and "white twostorey houses" were closer in appearance to turn-of-the-century garden-cities than to the traditional Russian village (Kremnev, 1976, p. 82). 
historian Basile Kerblay, the very ideals structuring the utopia reflected more the influence of "the cosmopolitan Russian intelligentsia rather than [that of] the peasant tradition" (1986, p. xlvi). As a self-proclaimed peasant democracy this was, in other words, a society manifestly vulnerable to charges of hollowness.

Instead of ignoring such possible accusations, Chayanov accommodated them within the text: Kremnev would recoil from the peasant utopia's intellectual vanguardism - with no doubt deliberate hypocrisy given his Bolshevism - and denounce it as "no more than a sophisticated oligarchy of a couple of dozen very clever and ambitious men" (Kremnev, 1976, p. 100). The accommodation of such objections was fully in line with the ethos of relativistic pluralism attributed to Chayanov by Nikulin. However, though he anticipated these criticisms, it is doubtful whether Chayanov would have fully agreed with their thrust. Tellingly, in the taxonomy of world political systems that Chayanov projected onto the world of 1984, a distinction was drawn between the Russian system of rule and the "intellectual oligarchy" implemented in post-1920s France (Kremnev, 1976, p. 87) - a distinction which suggests that Russian-style cultural elitism could not be, in Chayanov's view, equated with French-style intellectual oligarchy. More generally, Chayanov's commitment to the ascendancy of the peasantry had long been combined with a demand for its spiritual transformation. It is, therefore, unlikely that he would have seen the two potentially contradictory goals of preserving and transforming the peasantry as being seriously in conflict. The failure to see any contradiction was likely facilitated by Chayanov's primarily structural understanding of the peasantry, which treated their cultural characteristics as secondary to their economic location ${ }^{21}$. Since peasant culture was not understood as central to peasantness, remodelling it according to the tastes of an intellectual vanguard may not have struck Chayanov as an act of de-peasantization.

Furthermore, though Chayanov's utopia celebrated elite culture and assigned intellectuals a position of primacy, it remained a place with a deep aesthetic fondness for the peasantry. We can deduce this not just from the utopia's preservation of many of peasant Russia's external features (e.g., coloured carts, country fairs, handcrafts) - however sanitised these may have become - but also from its very framing as a peasant utopia. This framing should not be taken for granted. After all, Chayanov's imaginary future was a site not just of peasant labour and de-ur-

${ }^{21}$ In an example of his structural understanding of what made the peasants peasant-like, Chayanov would claim "that if Rothschild were to flee to some agrarian country, given a social revolution in Europe, and be obliged to engage in peasant labour, he would obey the rules of [the peasant economy] established by the Organization and Production School, for all his bourgeois acquisitive psychology" (Bourgholtzer, 1999, p. 44). 
banisation, but also of extensive rural modernisation, acculturation and quasi-suburbanisation $^{22}$. That the title of the text emphasised peasant triumph rather than the "city coming to the village" arguably said more about Chayanov's aestheticideological predilections than about the objective characteristics of his imaginary society ${ }^{23}$.

\section{Intentions and Meanings}

Difficulty of definition is not a problem limited to the utopia's political and ideological regimes. Rather, the meaning of The Journey is generally hard to pin down on account of the opacity of Chayanov's authorial intentions. Was his utopia one he endorsed as a societal blueprint or was it principally a parody of the utopian genre, too ironic and playful to qualify as a form of programmatic political thought? Militating in favour of the first interpretation is The Journey's consistency with many of the themes and arguments formulated in Chayanov's more academic writings. Indeed, Chayanov himself classed The Journey amongst his major scientific - as opposed to literary - works when under interrogation by the OGPU (Bourgholtzer, 1999, p. 27). Nevertheless, such academic aspirations did not stop Chayanov from writing a text that was rich in (self-)irony, open-ended imagery, literary references and multivocality - literary qualities that, whilst not always successful in their style of execution ${ }^{24}$, significantly complicate any literal understanding of The Journey. This final section will, therefore, consider how scholars have understood Chayanov's authorial intentions in relation to both the content and literary form of the utopia, and highlight some possible shortcomings of this treatment.

Interested as they usually are in the political and scientific dimensions of Chayanov's thought, historians and social scientists have often been inclined to overlook The Journey's formal qualities and the interpretive problems that these might pose. As a result, many of them have tended to ascribe unambivalent programmatic meanings to the text. One historian to whom this generalisation does not apply -

${ }^{22}$ Indeed, Minin himself admitted that: "it is time to give up the old-fashioned division between town and country, because all we have is a more or less dense distribution of the same agricultural population" (Kremnev, 1976, p. 82).

23 "The city coming to the village" would be a standard narrative structure in the urbanist utopias of the late 1920s (Clark, 1985, p. 184).

${ }^{24}$ Where Nikulin treats Chayanov as a master of the utopian genre (2017, p. 9), Gerasimov (1997, pp. 189-190) and Raskov (2014, paragraph 10) have both asserted a total lack of literary skill in his writing. 
and who denied that The Journey should be read as a programmatic statement - is Il'ia Gerasimov. In an early (and manifestly anti-communist) study of Chayanov's literary production, Gerasimov used The Journey, alongside Chayanov's five short stories, to conduct a Jungian analysis of the "hidden psychological mechanisms" which could explain why so much of the "consciously anti-Bolshevik [...] Russian intelligentsia [transformed into the] consciously loyal cadres of the [sic] Soviet specialists" (1997, p. 189). In Gerasimov's view, The Journey had served Chayanov not to make a programmatic statement, but as a way of "clarifying his own ideas" in the context of the broader struggle "between emotions and reason, sober analysis and emotionally intoxicated ideology" that gripped Chayanov's soul in the aftermath of the October Revolution (1997, pp. 151, 134). According to Gerasimov, this lack of programmatic intent could be inferred both from The Journey's openended ending, which saw Kremnev released from prison "friendless and penniless, to live life in a Utopian country he hardly knew” (Kremnev, 1976, p. 106) ${ }^{25}$, and from the mixing of utopian and dystopian (i.e., totalitarian) features in the Russia of 1984, whose moral ambiguity prevented the reader from finding out "which of [Chayanov's] protagonists turned out to be right in the end" (Gerasimov, 1997, p. 153). For Gerasimov, the only aspect of his utopia which would attract Chayanov's unequivocal approbation was, in fact, its "new culture" - a form of postmodernism avant la lettre in which the modern and the traditional hybridised in bizarre ways and a playful relativism disguised the absence of a positive programme (1997, p. 154). Chayanov's prose style, with its wealth of parodic elements, was similarly permeated with this postmodern spirit, thereby transforming The Journey into "a consciously planned literary game, a process for its own sake" (Gerasimov, 1997, p. 155). For Gerasimov, this postmodern relativism also held the key to his central question about why anti-Bolshevik intellectuals like Chayanov ended up in the Bolsheviks' service. It was Gerasimov's contention that Chayanov's generation of professional intellectuals combined a conscious, quasi-postmodernist rejection of positive value systems, on the one hand, with an enduring, unconsciously positivist mentalité that oriented them towards "the constant quest to improve any given circumstances under any given conditions", on the other (1997, p. 157). This combination of postmodernist nihilism and positivist professional ethics made these intellectuals vulnerable to self-deception in the face of Bolshevik advances, encour-

25 Gerasimov does not consider the possibility that there might have been a second half of The Journey which was blocked by state censors, causing the first half to appear open-ended. Whilst it is possible that Chayanov never got round to writing the second half, Katerina Clark (1985, p. 179) has stated that it was in fact withheld from publication, albeit without offering any evidence for this claim. 
aging them to ignore their qualms and offer their professional assistance to a totalitarian regime which would clearly have no regard for their professional ethics (Gerasimov, 1997, pp. 159-160).

Aside from Gerasimov, those who have most relied on textual analysis to lay bare the ambiguity of The Journey's message have, rather predictably, been literary scholars. One such scholar is Natalia Mikhalenko, who has drawn attention to the way Chayanov deployed Babylonian $(2016 ; 2020)$ and Promethean (2017) imagery to warn against utopian hubris - even as he constructed his own utopian Tower of Babel. Another such scholar is Pavlova who, like Gerasimov, also rejected programmatic understandings of The Journey on the grounds, first, of its parodic qualities and, second, its ambivalent multivocality. Chief amongst the parodic qualities discussed by Pavlova was the incongruous juxtaposition of a documentary style designed to make the utopia seem credible with continuous reminders of its literariness that shattered any illusions of credibility. Thus, on the one hand, The Journey was peppered with quotations from utopian newspapers and "facts" from utopian history books, which explained the chain of events leading from the real events of 1917 to the imaginary Russia of 1984 . On the other hand, chapter headings continually drew attention to the literary purpose they were meant to perform (e.g., "Chapter 9: Which young lady readers may skip, but which is recommended for the particular attention of members of the Communist Party"; Kremnev, 1976, p. 87), whilst within the body of the story the words "utopia" and "utopian" were repeated in a "refrain-like" (Pavlova, 2005, pp. 299-300) and often tongue-in-cheek fashion, as when Kremnev discovered he was "positively crazy about Utopian women" (Kremnev, 1976, p. 83) - an aspect of the new world which was presumably identical to the old. Though Pavlova does not say so explicitly, such recurrent instances of irony and parody cast doubt on the seriousness of Chayanov's programmatic intentions in engaging with the utopian genre.

The other complicating factor identified by Pavlova in The Journey - its multivocality - was a function of the text's implicit dialogical structure, in which two alternative "path [s] to Russia's revolutionary reconstruction" - one Marxist, the other Narodnik - were pitted against each other (2005, p. 324). Though initially structured as a contrast between the dystopia of 1921 and the utopia of 1984, this opposition would be blunted, as the discovery of "despotic traits" in the peasant utopia exposed "the inevitable dialectics of all utopian ideals" (Pavlova, 2005, pp. 296, 324). These "dialectics" were further accentuated by the circularity of The Journey's narrative structure: initially disenchanted with socialism, Kremnev would find himself re-enchanted by the peasant utopia, only to be disenchanted once again by his discovery of its despotism and subsequent stint in prison. Thus, pace Gerasimov, 
Pavlova saw the story's ending as a meaningful element of its narrative structure rather than a sign of its vacillation. Even so, Pavlova's overall verdict on what the text meant clearly recalled Gerasimov's: notwithstanding its proximity to Narodnik ideals, The Journey ultimately lacked faith in its own utopian vision. Its circularity was a reflection of "its author's pessimistic world-view: having lost its awareness of the metaphysical depths of being, contemporary humanity - consumed by its fanciful new role as the 'builder of earthly paradise' - would be doomed to thrash about hopelessly in between various utopias" (Pavlova, 2005, p. 352).

By paying attention to its prose style, internal conflicts and narrative structure, Gerasimov and Pavlova helped expose the normative ambiguities in Chayanov's text that earlier scholarship had tended to ignore. In so doing, however, these authors also likely overstated the extent to which the programmatic aims of Chayanov's utopia were nullified by its relativism. Though Chayanov recognised the arrogance of utopian thinking and the inevitable imperfection of all utopias, this self-awareness and the irony it generated need not be read as lack of commitment to the society he envisaged. Instead of signalling pessimism, the fallibility of Chayanov's utopia may have stemmed from a conscious desire to make it realistic. If wars and prisons were inevitable, then the peasant utopia was hardly discredited when - at a time of war - it arrested Kremnev on suspicion of espionage, only to release him for want of evidence. Far from exposing the equivalency of all utopias, this episode likely served to illustrate the opposite - the peasants' ethical superiority over the Bolsheviks who would surely have had Kremnev shot. Indeed, the way this section of the text was constructed lends credence to such a flattering reading for the peasant utopia. By warning the reader that Kremnev would soon experience "the bad organisation of places of confinement in the land of Utopia [...]", the chapter subtitle helped elicit a sense of comic incongruity when the benevolence of this "bad organisation" was later revealed: "the prison commandant came into the hall and again apologised to the assembly for their deprivation of liberty and the intolerable accommodation; he expressed the hope that all would be free in a couple of days, and promised to make up for the inconvenience by a good meal and various entertainments" (Kremnev, 1976, pp. 103-104). Only for a Bolshevik who saw a prison's worth in the efficacy of its terror would such "bad organisation" appear as a serious vice.

In their failure to consider the potential for a positive reading of what was supposed to be one of the peasant utopia's most dystopian facets, Gerasimov and Pavlova - both of whom warned against taking the utopia too seriously - may have fallen foul of their own hermeneutical recommendations. Whilst the utopia was certainly complicated by the presence of negative features, to think that these eroded its utopian status would likely be to treat these features far too seriously. 
More generally, Gerasimov's and Pavlova's one-sided interpretation exemplifies a broader oversight in Chayanovan scholarship - a failure to appreciate the role that a certain (ironically tinged) historical realism played in Chayanov's utopian thinking. As will be shown, this failure explains why scholars have overstated the dystopian implications of the peasant utopia's negative features. To illustrate how scholars have overlooked the importance of historical realism to Chayanov, it suffices to consider how they have interpreted the utopia's attitude to the revolutionary past. In one widely-discussed passage, Kremnev expressed his surprise at the presence of a "memorial to the architects of the great revolution", in which Lenin, Kerensky and Milyukov - political adversaries in 1917 - were represented "amicably supporting one another"; in response, Minin explained how "to us, from a historical perspective, [Lenin, Kerensky and Milyukov] were comrades in a single revolutionary effort, and, believe me, the present-day Muscovite doesn't remember very much what was the difference between them" (Kremnev, 1976, p. 79). This passage has been variously interpreted. Nikulin saw it as an expression of "liberal compromise" (2018, p. 265) between opposing political traditions, in keeping with his focus on the utopia's pluralistic spirit. Gerasimov, by contrast, read it as a sign of the peasant utopia's depoliticised character (1997, p. 143). Finally, Pavlova interpreted the monument as yet another manifestation of its totalitarian governance: a symptom of "a mythologizing view of history, devoid of the axiological differentiation of factual data and underpinned by a reconstructed cosmogonic model, juxtaposing chaos (revolution) and cosmos (the peasant Eden)" (2005, p. 342). Despite their differences, these interpretations all share the same underlying assumption, to wit, that what the monument primarily revealed must have been a specific feature of the peasant utopia. None notices how the monument disguised a more general, ironic observation about the transhistorical tendency for all societies to forget, to mythologise the past and to erase past conflicts - a tendency which even Chayanov's utopia (or the memory of his own revolutionary present) would not be immune from.

A closer glance at the text reveals many such ironic observations about the ineluctability of historical patterns and processes. Just as societies - including utopian ones - misremembered their revolutionary pasts, so all revolutions ultimately lost their momentum, reactions gave rise to counter-reactions and the gap between ideals and reality frequently grew. This was a destiny that would envelop the Russia of 1984 as much as that of 1917. After 1917, for instance, the futurist school of painting which had initially been so "utterly disruptive of old traditions" would give way to "a period of baroque futurism, of tame and charming futurism” (Kremnev, 1976, p. 77). Pace Clark (1985, p. 182), this does not signify 
Chayanov's rejection of futurism so much as his appreciation of the transhistorical dynamics of artistic fashion and style. In the new Russia, meanwhile, observance of the "sacred" decree on the dissolution of cities was gradually loosened, to the point where Moscow's councillors in 1984 had to concoct various cartographical tricks to disguise the fact that Moscow had accumulated far more than its official 30,000 residents (Kremnev, 1976, p. 80). Literary allusions confirmed that these instances of failed revolutionary ambition - the taming of a once radical futurism, the re-urbanisation of a once de-urbanised Moscow - were in keeping with much broader historical patterns. The passage from Alexander Herzen which set off Kremnev's meditations on the future at the beginning of The Journey was one which anticipated how after its victory "socialism, in the position of today's conservatism, will be defeated by another, unknown revolution still to come" (Kremnev, 1976, p. 74). Later on, we are told about how Pushkin's statue had tried to remind the revolutionary crowds in Moscow - be it in 1905, 1917, 1932, or 1937 of the tale of the fisherman and the fish, a tale whose moral concerns the pitfalls of excessive "political" greed. Unsurprisingly, the revolutionary crowds ignored the warning (Kremnev, 1976, p. 81).

Given that it could no more escape historical circularity than its Bolshevik predecessor, what was there to distinguish the peasant utopia, to prove it was built to last? To believe Gerasimov and Pavlova, of course, Chayanov's pessimism prevented him from making any such distinction. It is certainly the case that neither the utopia's leaders nor its narrator would claim that the peasant utopia had ended history for good. Paradoxically, however, the very historical realism that likely precluded such a claim - when internalised by utopian elites - was also the best guarantee of historical stability for the utopia. Recognising the obduracy of history and nature, the peasant utopia would seek to align itself with both, to enshrine "eternal principles" and avoid gratuitous novelty, thereby protecting itself from historical reversals. Where changes were desired by utopian elites (e.g., in modernising the peasant economy and promoting rural high culture), their historical realism pushed them to make these changes self-sustaining, eschewing reliance on permanent state coercion (Kremnev, 1976, pp. 88, 100). Chayanov's historical realism may have resulted in an imperfect utopia, but the realism which he imparted to his utopian elites was manifestly a source of strength. The Bolsheviks had tried to usher in the final stage of history and failed. Free as it was of such hubristic aspirations, the peasant utopia came all the closer to fulfilling the Bolsheviks' ambition. Rather than reflecting Chayanov's relativistic vacillation, the imperfection of the peasant utopia signalled its success - the endurance that came with being conceived within a reality that was historically constrained, rather than quixotically outside of it. 


\section{Conclusions}

Though the last three decades have seen multiple studies dealing with Chayanov's utopia, little dialogue has been conducted between them. For this reason, the present article has sought to provide an integrated overview of recent research on The Journey across different disciplines and languages. The article identifies three aspects of this scholarship that have yielded the greatest diversity of interpretations. The first of these is the variety of contextual framings adopted in relation to The Journey. By respectively viewing the utopia through the prism of $20^{\text {th }}$-century anti-socialism, post-1917 utopianism, urbanist vs anti-urbanist conflicts in Russian/ Soviet culture, and the literary trends of the Russian Silver Age, different scholars have brought different aspects of the text to the fore. These have included The Journey's (questionable) conformity with the broader tropes of agrarian populist anti-socialism; its representativeness of the ideals of the February Revolution and of a transhistorical variety of "chancellor-like" utopianism; the mixing of urbanist and anti-urbanist features in its utopian vision; and, finally, an aesthetic that reflected the prevailing post-1900 literary Zeitgeist in Russia.

If a diversity of contextual framings has mostly reflected a diversity of research questions rather than genuine disagreement, more tensions can be observed - even if they are not always acknowledged - between different scholars' attempts to classify the utopia's dominant ideology and system of governance (the second source of interpretational diversity identified in this article). In explaining why different ideological labels have been used in relation to The Journey, I have sought to show that there is sufficient intra-textual evidence both to trace the intellectual influences of socialist, Narodnik, liberal and conservative thought and to deny any one of these influences absolute primacy. The potential for both totalitarian and liberal, elitist and democratic readings of the utopia's political system was also explored. Finally, the article has discussed how interpretations of The Journey have varied depending on their understanding of (and willingness to recognise) its literary and parodic qualities as well as its allegedly dystopian elements.

Throughout the article I have drawn attention to the shortcomings of the existing literature. In particular, I have pointed out the relative failure of certain contextual framings (especially Tom Brass' typological approach); the textual misunderstandings that underlie totalitarian readings; and how interpretations that accentuate pessimistic relativism as a core element of The Journey have overlooked the positive role played by historical realism and irony in Chayanov's utopian vision. Finally, though The Journey is already a thoroughly researched text, I have 
also suggested possible directions for future research. In particular, future scholars should prioritise contextualising The Journey not only within Chayanov's broader oeuvre - to investigate the (dis)continuity of socialist and liberal ideological elements - but also, and more importantly, within the larger complex of $20^{\text {th }}$-century agrarian thought in Russia and Europe. Given the utopia's affinities with this political and intellectual tradition, the latter perspective is essential to grasp how far The Journey conformed to or diverged from this wider ideological tendency and the "futurological" visions it engendered.

\section{References:}

Bernstein, H., \& Byres, T.J. (2001). From Peasant Studies to Agrarian Change. Journal of Agrarian Change, 1(1), 1-56. DOI: 10.1111/1471-0366.00002.

Bourgholtzer, F. (1999). Aleksandr Chayanov and Russian Berlin. The Journal of Peasant Studies, 26(4), 13-53. DOI: 10.1080/03066159908438717.

Brass, T. (1991). Moral Economists, Subalterns, New Social Movements, and the (Re-) Emergence of a (Post-) Modernized (Middle) Peasant. The Journal of Peasant Studies, 18(2), 173-205. DOI: 10.1080/03066159108438449.

Brass, T. (1996). Popular Culture, Populist Fiction(s): The Agrarian Utopiates of A.V. Chayanov, Ignatius Donnelly and Frank Capra. The Journal of Peasant Studies, 24(1-2), 153-190. DOI: 10.1080/03066159608438634.

Bruisch, K. (2012). Krest' ianskaia ideologiia dlia krest'ianskoi Rossii: agrarizm v Rossii nachala XX veka. In: Krest'ianovedenie: teoriia, istoriia, sovremennost'. Vol. 7 (pp. 142-158). Moscow: Izdatel'skiy Dom "Delo".

Bruisch, K. (2018). Knowledge and Power in the Making of the Soviet Village. In: L. van de Grift, \& A. Ribi Forclaz (Eds.). Governing the Rural in Interwar Europe (pp. 139$-163)$. London/New York: Routledge.

Clark, K. (1985). The City versus the Countryside in Soviet Peasant Literature of the Twenties: A Duel of Utopias. In: A. Gleason, P. Kenez, \& R. Stites (Eds.). Bolshevik Culture: Experiment and Order in the Russian Revolution (pp. 175-189). Bloomington: Indiana University Press.

Coleman, W., \& Taitslin, A. (2008). The Enigma of Chayanov. In: V. Barnett, \& J. Zweynert (Eds.). Economics in Russia: Studies in Intellectual History (pp. 91-105). Burlington, VT: Ashgate.

Freeden, M. (1996). Ideologies and Political Theory: A Conceptual Approach. Oxford: Clarendon Press.

Gal, S. (2019). Making Registers in Politics: Circulation and Ideologies of Linguistic Authority. Journal of Sociolinguistics, 23(5), 450-466. DOI: 10.1111/josl.12374.

Gerasimov, I. (1997). Dusha cheloveka perekhodnogo vremeni: sluchă Aleksandra Chaianova. Kazan: Izdatel'stvo "ANNA". 
Kerblay, B. (1986). A.V. Chayanov: Life, Career, Works. In: A. Chayanov, D. Thorner, B. Kerblay, \& R.E.F. Smith (Eds.). A.V. Chayanov on the Theory of Peasant Economy (pp. xxv-lxxv). Manchester: Manchester University Press.

Kremnev, I. [Chayanov, A.V.] (1976). The Journey of My Brother Alexei to the Land of Peasant Utopia. The Journal of Peasant Studies, 4(1), 63-108. DOI: $10.1080 / 03066157608438004$.

Mendras, H. (2002). The Invention of the Peasantry: A Moment in the History of PostWorld War II French Sociology. Revue Française De Sociologie, 43, 157-171. DOI: $10.2307 / 3322761$.

Mikhalenko, N.V. (2016). Simvolika Vavilonskoy Bashni v 'Puteshestvii Moego Brata Alekseia v Stranu Krest'ianskoi Utopii' A.V. Chaianova. Problemy Istoričeskoj Poètiki, 1, 428-440. DOI: 10.15393/j9.art.2016.3821.

Mikhalenko, N. (2017). Theurgic and Promethean Aspects of Alexander Chayanov's The Journey of My Brother Alexei to the Land of Peasant Utopia. Societal Studies, 9(2), 201-205. DOI: $10.13165 /$ SMS-17-9-2-07.

Mikhalenko, N.V. (2020). Images and Symbols of Ancient Civilizations in the Works of Dmitry Merezhkovsky and Alexander Chayanov in the Context of the Literary and Philosophical Process of the Late Nineteenth-Early Twentieth Centuries". Studies in East European Thought, 72(3-4), 351-362. DOI: 10.1007/s11212-020-09372-4.

Nikulin, A.M. (2017). Chaianovskiy utopizm: balansiruia sredi krizisov intensifikatsii optimumov. Krest'ianovedenie, 2(1), 6-30. DOI: 10.22394/2500-1809-2017-2-1-6-30.

Nikulin, A.M. (2018). Grezy Russkoi revoljutsii v utopiiakh Aleksandra Chaianova i Andreiia Platonova. Sotsiologicheskoe Obozrenie, 17(3), 256-290. DOI: 10.17323/1728192X-2018-3-256-290.

Pavlova, O.A. (2005). Russkaia literaturnaia utopiia 1900-1920-kh gg. v kontekste otechestvennoi kul'tury. Volgograd: Volgogradskoe nauchnoe izdatel'stvo.

Raskov, D. (2014). Socialist Agrarian Utopia in the 1920s: Chayanov. OEconomia, 4(2), 123-146. DOI: https://doi.org/10.4000/oeconomia.836.

Robinson, P. (2019). Russian Conservatism. Ithaca, NY: Cornell University Press.

Scott, J. (1998). Seeing Like a State: How Certain Schemes to Improve the Human Condition Have Failed. New Haven/London: Yale University Press.

Shanin, T. (1986). Chayanov's Message: Illuminations, Miscomprehensions and the Contemporary 'Development Theory'. In: A. Chayanov, D. Thorner, B. Kerblay, \& R.E.F. Smith (Eds.). A.V. Chayanov on the Theory of Peasant Economy (pp. 1-24). Manchester: Manchester University Press.

Stites, R. (1989). Revolutionary Dreams: Utopian Vision and Experimental Life in the Russian Revolution. New York/Oxford: Oxford University Press.

Thorner, D. (1986). Chayanov's Concept of Peasant Economy. In: A. Chayanov, D. Thorner, B. Kerblay, \& R.E.F. Smith (Eds.). A.V. Chayanov on the Theory of Peasant Economy (pp. xi-xxiv). Manchester: Manchester University Press. 